\title{
Foreign Influences Designing Albanian Schools Architecture
}

\author{
Ledita Mezini \\ Lecturer at Faculty of Architecture and Urban Planning, Polytechnic University of Tirana, Albania
}

\begin{abstract}
Throughout history, Albania was a battlefield of several wars, assaulted from other countries and always struggling to survive and preserveits traditions, language and culture. Invasions happened through guns and battles but also through the extent of foreign languages and culture ineducation. The education sector and structures that hosted it, passed through stages of transformations, developments and regressions dependent on the course of history and the forces of foreign countries shaping it. The main objective of this research is to highlight the Albanian school buildings through two parallel points of view: an outlookthrough the course of history and analyzed as structures. This article tries to explore the changes that occurred in educational buildings in Albania.Itfocuses on the influences, problems and issues that have emerged, during the several invasions and how these influences have affected the architecture of Albanian's schools. This analysis is followed by a discussion of the architecture's development and the typology, standards, structures and shapes of this category of buildings focusing mostly on the last century, trying to fill the gap of history and knowledge for this important group of edifices.
\end{abstract}

Keywords: Albania, school architecture, transformation of buildings, history, educational structures.

\section{Introduction}

"The physical and typological changes in schooles architecture have always been influenced from sociopolitical, economical, and ideological changes in education of the society. These changes have shaped the concept of child development, the attitude toward the education practice, and the type of educational buildings as well as their physical and social form, which were developed as agent of socialization." [1]

To study the architecture of a group of buildings, it should be analyzed through progression of history and look back to the story of evolution from the begging to the problems and the variations of forms over the years. The researcher Koliqi in his book "History of the Albanian education and the pedagogical thinking", believes that it can be divided into four main stages: the old time frame, the medium, the new time frame and the newest one. [2] While according to the researcher Ceka education in Albania canbe divided into two periods: the prehistoric in the order of primitive community where more attention was paid to the social norms (learning of craftsmanship, usage of tools from one person to the other), and the second period when social norms and education become proper activities. [3] "As in every historic division boundaries are artificial and the phases of variable change display elements of continuity." [4] Although there have been different division types from several researchers, it is clear that the origin or the proper development of the Albanian schools is attributed mainly to the beginning of the $\mathrm{XX}^{\text {th }}$ century, when most of the existing structures were built.

The Albanian history is related to the manyinvasions that happened during the Roman Empire, the Ottoman Empire and later the First and Second World War,the influences and forces that they brought. During the course of history invaders tried to impose their culture, language and traditions not only through battles and guns but also through the education of the youth. The education sector in Albania and the edifices that support it, suffered the course of history, transformed and shaped by these political and social events. Invaders enforced their languages, the culture, pedagogy and the architecture typology and design of this large and important group of buildings.

To understand the architecture of a collection of buildings you have to look back to the history of this typology and the different phases it has passed through.

Referring numerous researchers, Illyrians as also Albanians over the years did not study in schools, not wanting to learn under the rein of foreigners the Latin or Hellenic language. Instead they were educated by popular means. This particularity over the years has led, the Albanian education and schools to arise considerably late. "As we know so far, in the primitive Illyrian cities, there were no dedicated authentic educational institutions, schools." [5]

In the end of the IV century the Roman Empire was divided in two parts and the Albanian territories were found in the Byzantine Empire. The Ottoman expansion in the Balkans started in the thirteenth century, as Byzantium began to crumble. In Albania, it was aided by the local political fragmentation into many small principalities at war with each other.

As the Ottoman Empire weakened in the second half of the nineteenth century, a strong national independence movement, The Albanian National Awakening arise. It had anethnic identity prevailing over religious affiliation among the educated population.

First World War, corresponds with a difficult period for Albania which struggled between major powers trying to occupy it. Three Western European cultures dominated this period (Austro-Hungarian, French and Italian), and all three tried to occupy Albanian territories through the construction of school buildings and the spread of their language.

After the Second World War, a communist dictatorship was installed in Albania, which lasted until 1990. As a 


\section{International Journal of Science and Research (IJSR) \\ ISSN (Online): 2319-7064 \\ Index Copernicus Value (2013): 6.14 | Impact Factor (2015): 6.391}

communist country Albanian dictator Enver Hoxhaimposed the Soviet ideology and its buildings architecture (educational also) was influenced by the standard of the Marxist-Leninist ideological axis.

This article seeks to illustrate the issues and to explore the changes that have occurred in the educational buildings in Albania. It focuses on the influences, problems and concerns that have emerged, during the several invasions and how these powers have affected the architecture of Albanian's schools. This analysis is followed by a discussion of the architecturees development and the typology, standards, structures and shapes of this category of buildings. It focuses mostly on the last century, trying to fill the gap of history and knowledge for this important group of edifices.

This article is interdisciplinary and includes the history of education as well as that of design. Visual analysis methods are used and the main sources for analysis are pictures, plans of buildings and also publications, books, magazines, etc. These sources have been collected from the history of education and design to identify and categorize the designing language under the course of history and to explore how the foreign invaders transformed the schooles architecture.

\section{First Traces of School Buildings in Albania}

Archaeological and historical data show that the first traces of education in Albania date back to the prehistoric period. After the mid-first century BC, Roman policies were introduced in a large scale in the founded cities, including writing and Latin culture education. In Illyrian cities remains of gymnasiums have been found.[3]

The architecture of gymnasiums buildings in the Illyrian period is believed to be similar to the Roman one. While it has been discovered that the Illyrian cities developed three types of education, labor, physical and military education.

Dedja states that "The start of educational institutions, school is a phenomenon related to the slavery period and that according to archaeological data coincides with foundation of the Hellenic colonies. Therefore in the Illyrian cities there were mainly private primary schools, gyms, and gymnasiums, which were copied mechanically, but they were also created under the influence of the ancient Greek educational system, which was the most advanced for the time, almost worldwide."[5]

In the medieval period schools and education closely linked to the Christian church, and after that to the Islamic religious institutions."Albanian cities of oriental character turned into compact urban structures, chaotic, medieval and very similar to the structures of Muslim cities where the dominant units were 1-2 story private buildings, religious public mosques buildings or few Catholic or Orthodox churches and in the third rank some public commercial and handcrafting space." [6]

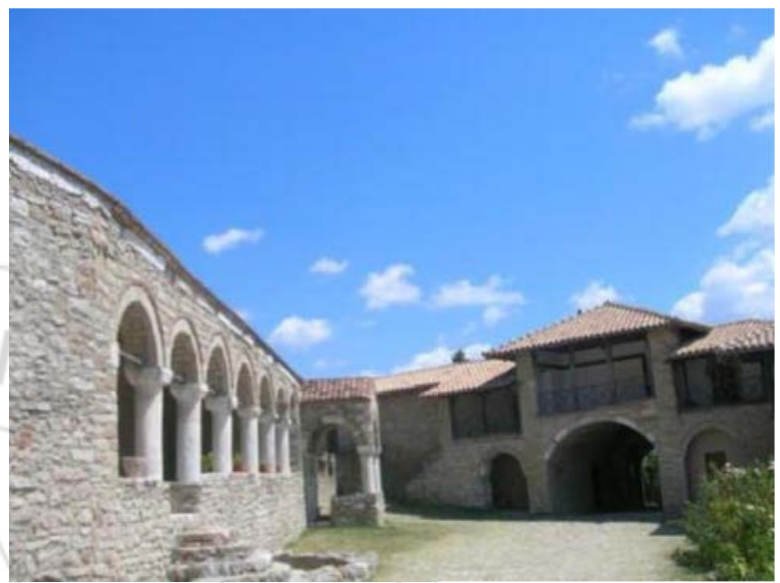

Figure 1: Monastery of Ardenica, Fier, Albania. Source by Author

Since substantially the core of the medieval city was the object of worship, the school or the place where teaching occurred were still places of worship, Islamic or Christian. The architecture of these buildings opened through inclusive porches or arcades were free for the public and for the whole population. As mentioned by Koliqi, the teachers were clerics or imams, and teaching too place close to churches (Catholic or Orthodox) called monasteries and then later in madrassas which were the first Islamic schools. [2]

As in other countries in Albania the architecture of schools started being related to the place of worship. Sunday School Buildings were the places where the cleric taught to the masses the Bible. [4] Essentially in the medieval city, school buildings were the object of worship, where it was again taught Islamic or Christian religious. 


\section{International Journal of Science and Research (IJSR) \\ ISSN (Online): 2319-7064}

Index Copernicus Value (2013): 6.14 | Impact Factor (2015): 6.391

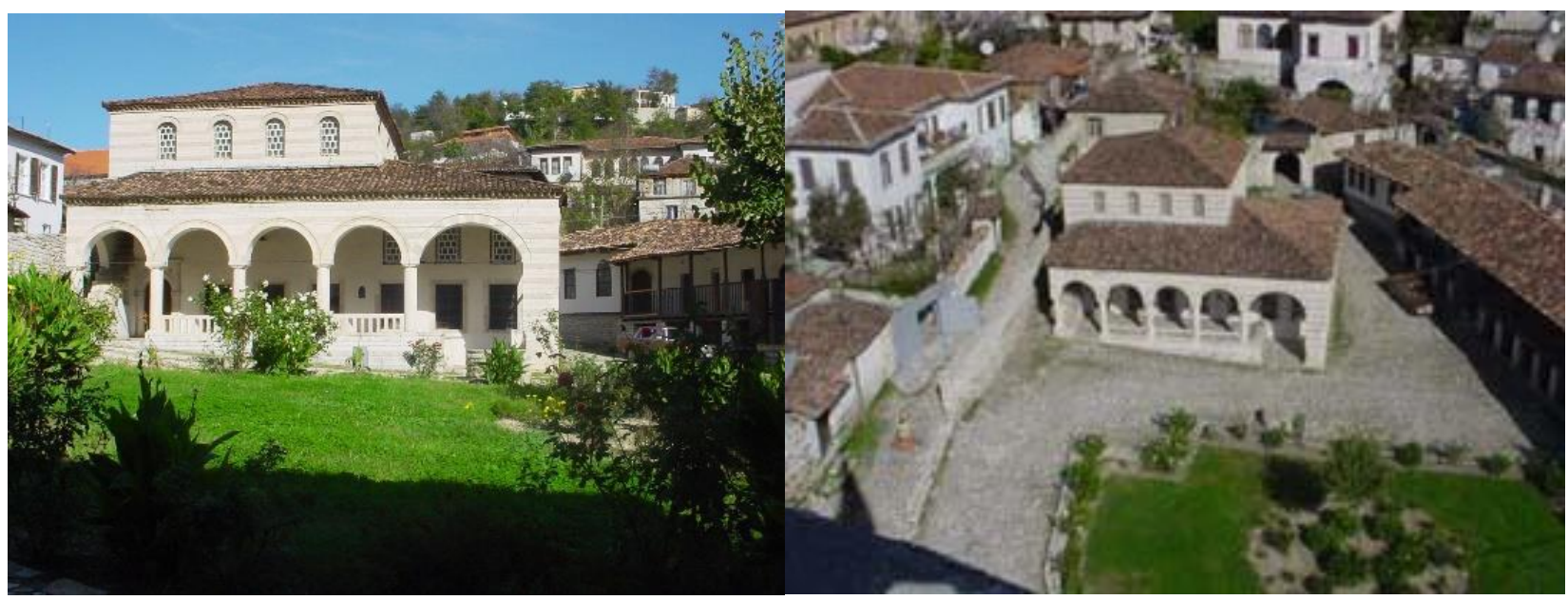

Figure 2: HelvetiMasjid, Berat, Albania. It dates back to 1492-1493. According to data next to the Small Mosque, has been linked the adjacent library. The library building was burned down during the First World War. The presence of the adjacent

library tells us that the building was not only the cult object to teach the youth of the Muslim religion but also the cityes school. Courtesy of Institute of Cultural Monuments of Albania.

Dedej writes "Education continues to be on clerices hand. During this period, in Albania operated three different types of schools: Catholic School in the north, Orthodox in the south, Turkish throughout Albania. "[7]

One major problem in new schoolse opening and physical structures $^{\text {ee }}$ building, was the fact that those few students who learned during this period, took private lessons (those few who could pay), "... in parishes and monasteries, were taking lessons from bishops and educated clerics and after continued their studies in high school in Venice, Ancona, Padua, Rome, Germany etc.” [7]

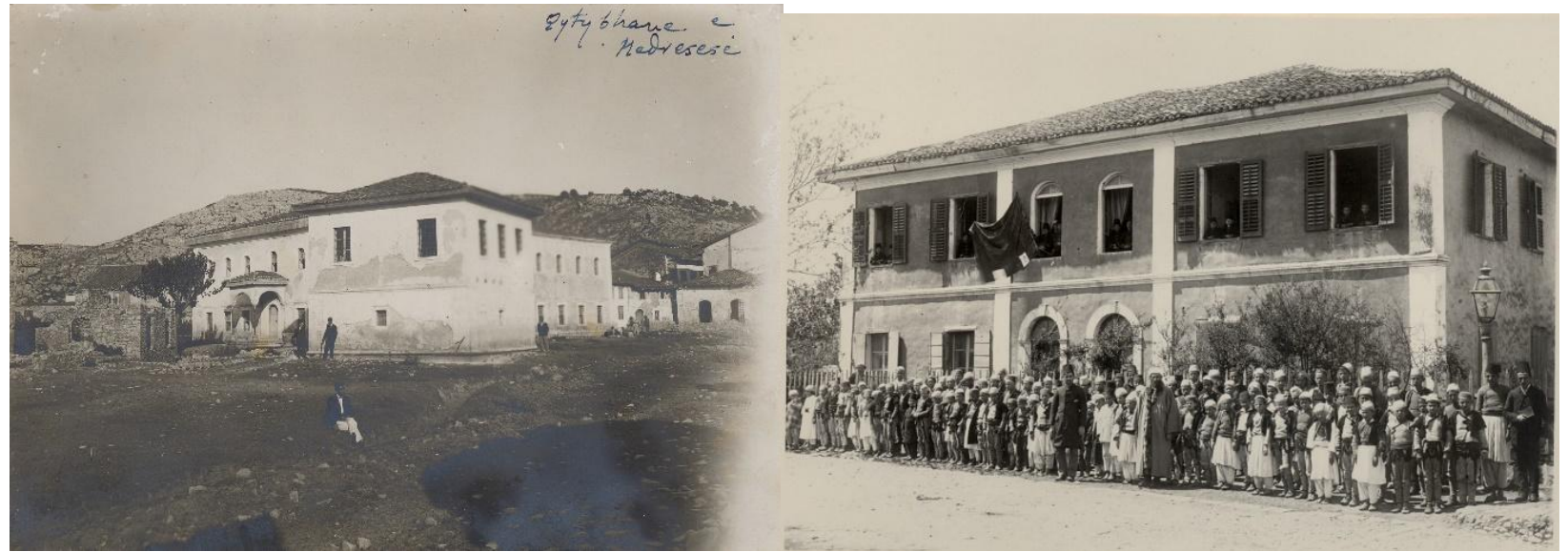

Figure 3: Above- The building of Madrassas and the library next to it, Shkoder city, built in 1760-1770. Down-mejtepe (elementary ottoman schools) 1876. Shkoder city, Photo courtesy: Central State Archive

Learning abroad the educated group of Albanians were also influenced and inspired by the culture, traditions and architecture of the foreign countries and brought their new methods of thinking in their own country.

During the Albanian National Awakening (1830-1912) in the 30-80 years of XIX century, two types of schoolswere created: those specifically for bourgeoisie"s children and the other for working masses ${ }^{\text {ee }}$ children".... elementary schools, where children of the working masses were taught continued to remain in deplorable conditions." [7]

As it can be understood the primary school architecture did not receiveattention and was left withneglected structures, built quickly without appropriate conditions for the development of teaching and learning purpose. This stage of history goes along with the evolution of school buildings abroad where two types were generated: Rural schools with one or two spaces, with a modest and economic architecture and urban schools, criticised as "Palace building"- for their size and pomposity. [8]

Gecaj underlines the fact that under the 500 years of Turk ${ }^{\text {ee }}$ s oppression there were much difficulties in finding the learning spaces and educational process was often done in the teacher's house, or elsewhere improvised. [9]

However in this period, 3 types of school typologytook place - "Normale" schools - which prepare new teachers, elementary schools and some vocational schools.

With the creation of the Albanian state on 28 November 1912 too little education experience was inherited from the administration of the Turkish invaders. For a long time in

\section{Volume 5 Issue 4, April 2016}




\section{International Journal of Science and Research (IJSR) \\ ISSN (Online): 2319-7064 \\ Index Copernicus Value (2013): 6.14 | Impact Factor (2015): 6.391}

Albania operated the mejtepe (elementary ottoman schools) type, set up near the mosque ... [10] While in the villages without waiting to build new buildings, classes began to develop around the house, hut, the animal sheds, which were adapted by villagers and teachers in schools. "[11]

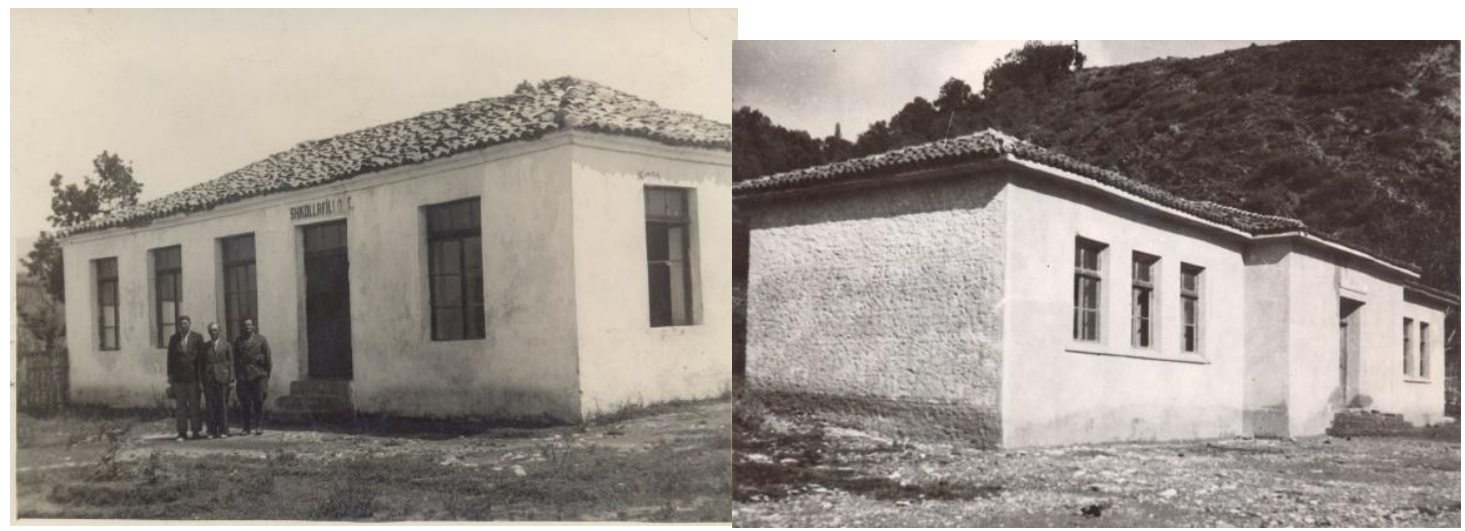

Figure 4: Albanian Schools were simple houses donated to the purpose of teaching and learning Albanian Language. Source: Central State Archive

"The last data regarding the XIX century, show that in the main four parts of Albania: Scutari, Kosovo, Monastir, and Ioannina, where Albanian were acompact and in a large number of population, there were: 1187 schools teaching Turkish language, more than 1000 schools teaching Greek, 300 schools teaching Serbian and Bulgarian, and an increasing number of schools in Italian and AustroHungarian. [12] Of the same opinion is also Koliqi who declares "Prevailing schools were primary schools in Turkish, Greek, while Catholic schools were in Italian, Bulgarian, Serbian, Vlach etc.” [2]

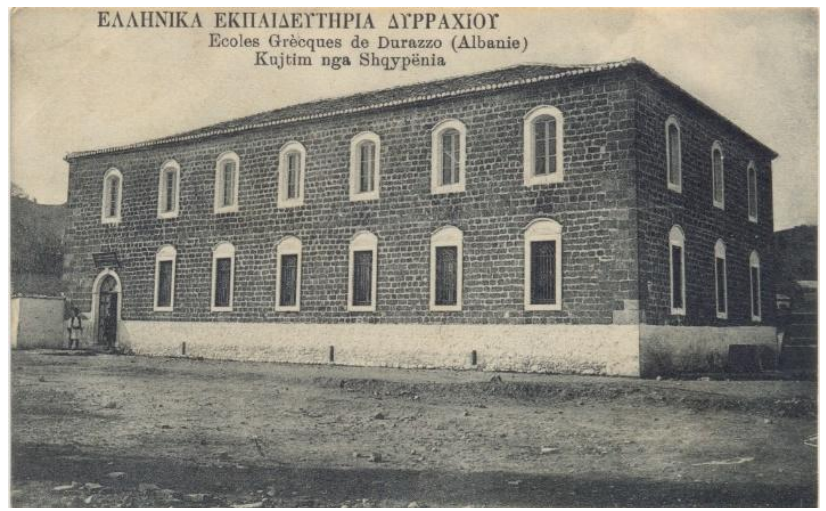

Figure 5: Greek School in Durres, Source: Central State Archive

\section{Education and the infrastructure builtduring the two World Wars.}

The first projects of school buildings are related to foreign influences. As Albania came out of a long period of occupation, knowledge regarding needs and requirements for the construction of schools were scarce.

First World War, corresponds with a difficult period for Albania with many major military powers trying to occupy it all. Three Western European cultures dominated this time (Austro-Hungarian, French and Italian). All the three authorities constructed different types of schools trying to invade through education. Even though these buildings were built by the aggressors it can be declared that these were the first educational building whose purpose was teaching and learning. The government of Rome and Austria-Hungary were the first ones that created foreign schools with a new and western ideology in Albania.

Starting in the 1910s, successive governments have imposed their urban design visions for a grand city architecture and tried to erase the built heritage of their predecessors, thus creating an eclectic space. [13]

From the data of the Central State Archive in the period 1916-1918, (the period of Austro-Hungarian occupation), a large number of schools were built across the country and mainly in the cities. Perhaps this statement is related to the fact that primary education was made compulsory for children 7-12 years old. While in most of the western countries educationbecame compulsory in 1900. (Baker, 2012) 


\section{International Journal of Science and Research (IJSR) \\ ISSN (Online): 2319-7064}

Index Copernicus Value (2013): 6.14 | Impact Factor (2015): 6.391
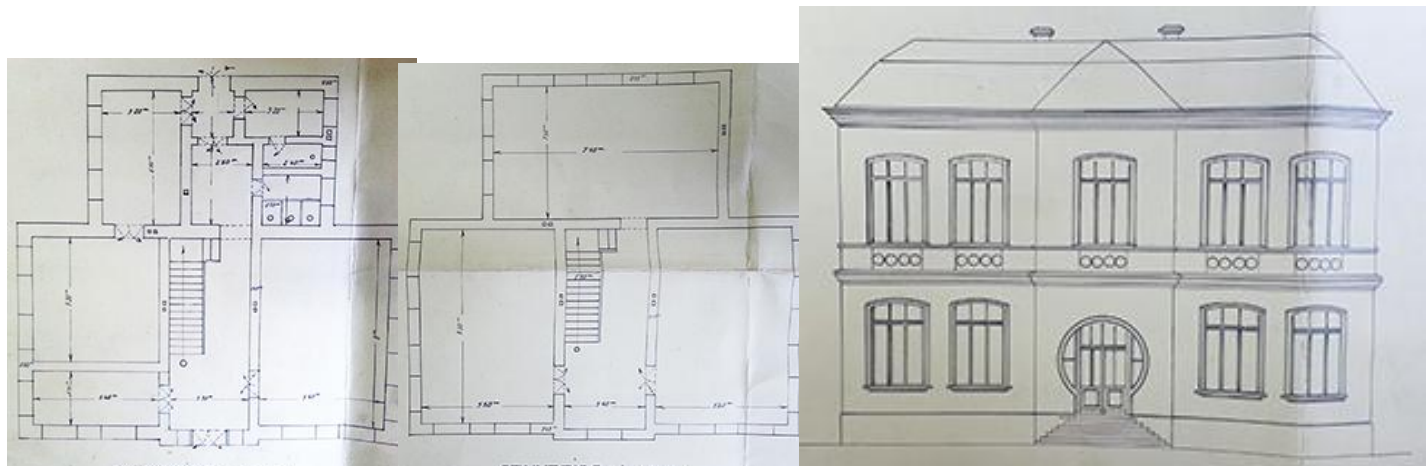

Figure 6: Ground,first floor plan and elevation, Austrian primary school, 1922. Courtesy of Central Construction Archive.

The Austrian architect Hans Koehler in 1927 designed a building which would be more than an instruction building, offering for the first time facilities that were unknown for the school architecture, like recreation room, dining, theater, kitchen, toilets, showers, etc.

Albanian Technical School "The Albanian Vocational School 'in Tirana opened July 21, 1921 by the Youth American Red Cross and had as theoretical and practical basis the pedagogical American pragmatist theory of John Dewey, according to which 'school is a community', 'education is life, "school activity relied on the fundamental principle of' learning by doing '. [2]

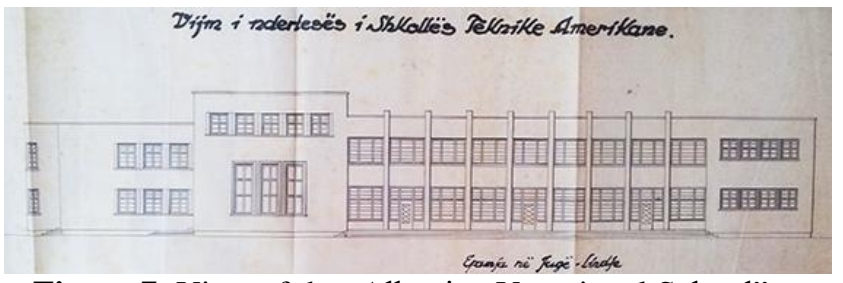

Figure 7: View of the „Albanian Vocational School”Courtesy of Central Construction Archive.

After a long period, where schools in Albania were represented more like residential buildings, warehouses, markets, and other unsuitable environments, the American high school building represented a major change and innovation in the image and symbolism of schools.

The positive side of the invasion from three major European powers as well as by the academic Osmani, was the fact that the three countries occupying Albanian territories reflected three advanced European experiences, of which students, teachers and buildings benefited. [15]The invading countries affected not only the language, culture, history, traditions, but also the educational programs. Plans for education were combined with educational concepts and culture of the occupying countries. [2]

According to Vokshi "Competition was entirely anattempt to put prevalence through Albanian territories" in which Austria-Hungary had sought to control the Adriatic Sea and Italy also began to show that it was a factorin the end of XIX century. [6]

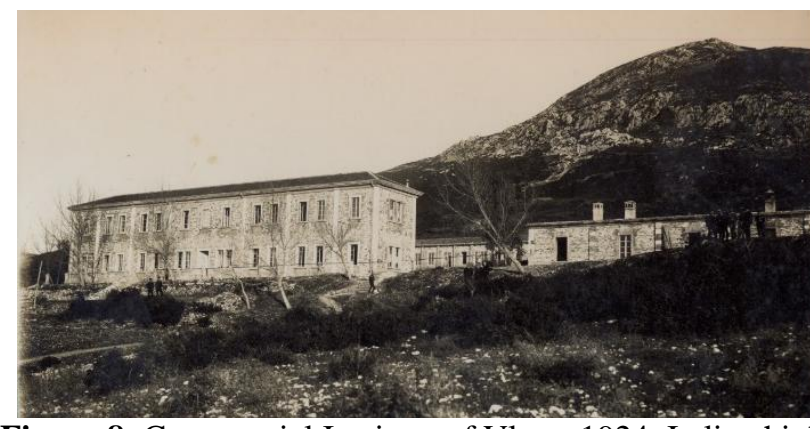

Figure 8: Commercial Institute of Vlora. 1924. Italian high school. Photo Courtesy: Central State Archive.

On 10 December 1916 the region of Korca was declared autonomous, and it also had a great impact on Albanian education. Under the French influence on October 25, 1917 a secondary school Lyceum opened, the first secondary school of general education in the country.

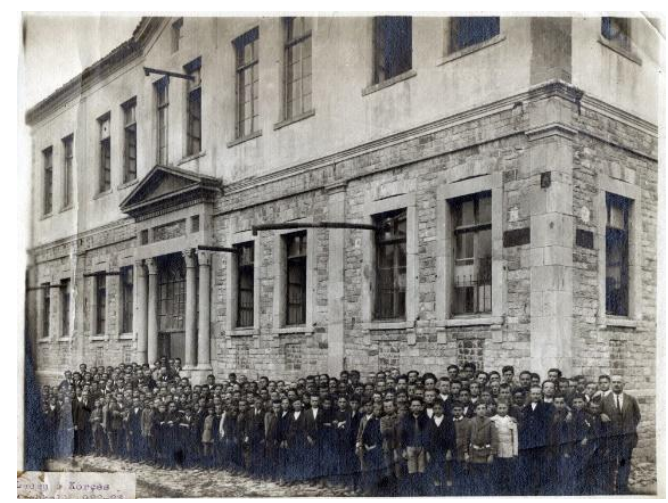

Figure 9: Photo of Lyceum of Korca which was the first secondary school of general education and in Albanian

language. Photo Courtesy: Central State Archive

The architecture of the school buildings during the 19251939, coincides with the reign of Ahmet Zoguand wasentirely acreation of the Italian architects who came to Albania.Theyhad the opportunity to design and create the basis of rational fascist architecture in a completelynew territory. Zogu let the Italian architects design freely in the Albanian territories mostly because of the large amounts of cash that the Italian government loaned to the Albanian regime. Architect Giulio Berte was one of the architects who designed several school buildings introducing to Albanian architecture a new typology in school design. This type of architecture was totally different from the Albanian traditional vernacular buildings which were similar to the Ottoman architecture. 


\section{International Journal of Science and Research (IJSR) \\ ISSN (Online): 2319-7064 \\ Index Copernicus Value (2013): 6.14 | Impact Factor (2015): 6.391}

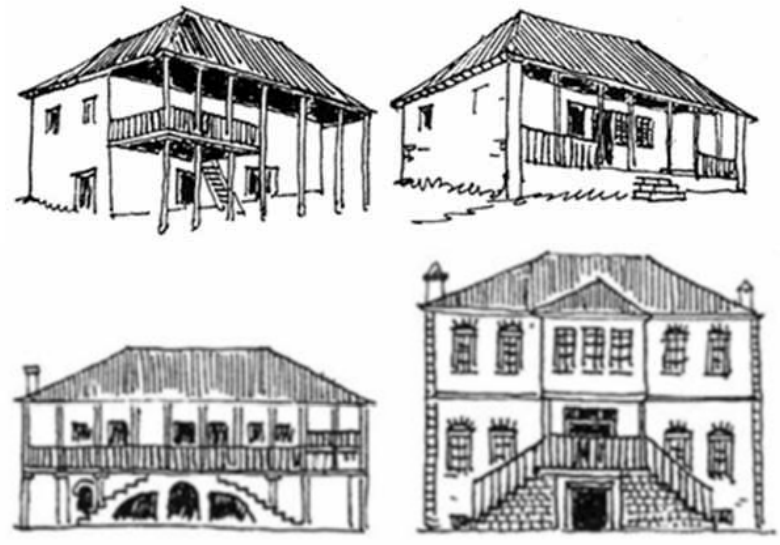

Figure 10: Non-defensible Ottoman-era house typologies in Albania. From the left: vate"rzjarri type, hajat type, cardak type, and qoshke" type. Illustrations courtesy of EminRiza and PirroThomo.

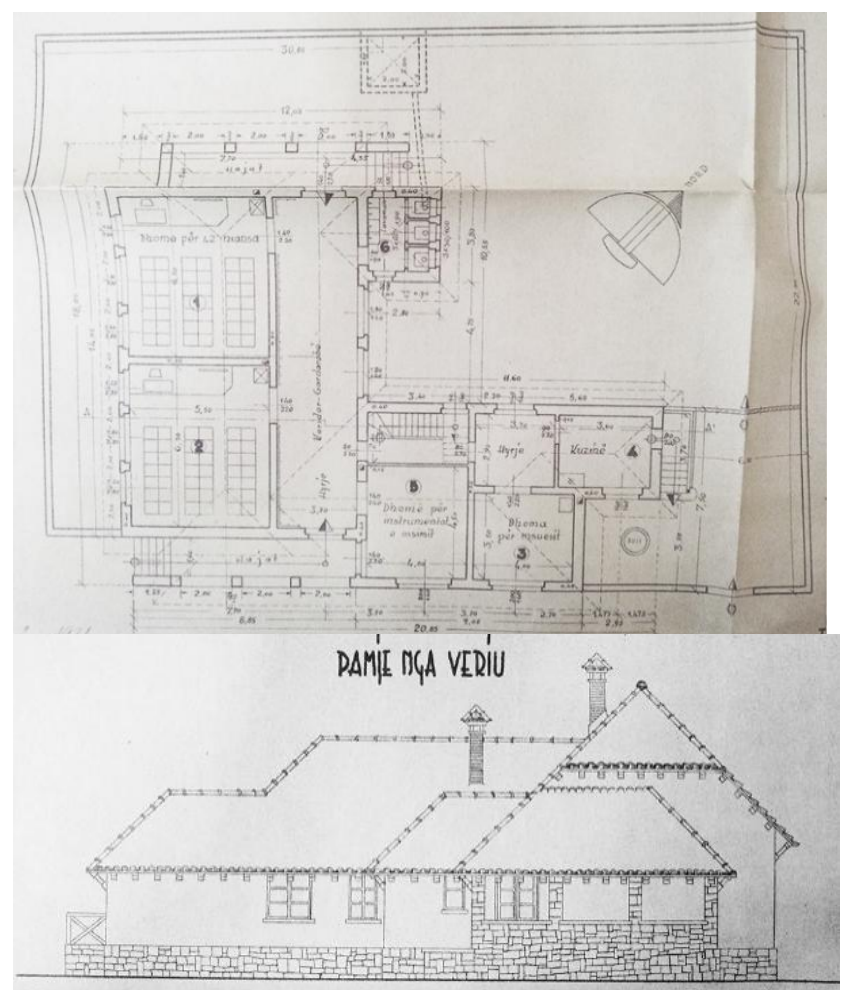

Figure 11: Plan and elevations of a primary school in north Albania, architect GiulioBerte, 1936, Courtesy of Central Construction Archive.

The Italian architects influenced the architecture of educational buildings and also the pedagogical methods because they were the first to set the standards. They brought new methods of teaching and learning based mainly in the theories of "learning by doing". School buildings were mostly vocational schools, with large classes and laboratories where students could learn and produce.

Fascist occupation on April 7, 1939 introduced to the education sector a very different direction including contents according to the Italian educational model.

The need to expand in a fast and simple way, primary, secondary and professional schools in the Albanian territories was mainly to teach to the children and youth the Italian language. This led to massive building of schools from the fascist Italy. These period was characterized by standardization. Italian architects unable to design unique architectural projects for so many schools across Albania in such a short time, began to plan the first standard types. These buildings, often needed to be constructed quickly using demountable and prefabricated panels.

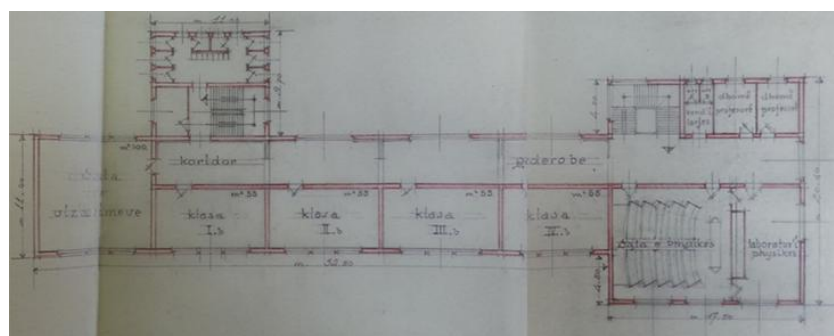

Figure 12: Plan of first floor of School in Korca. 1936. Architect Giulio Berte. Courtesy of Central Construction Archive.

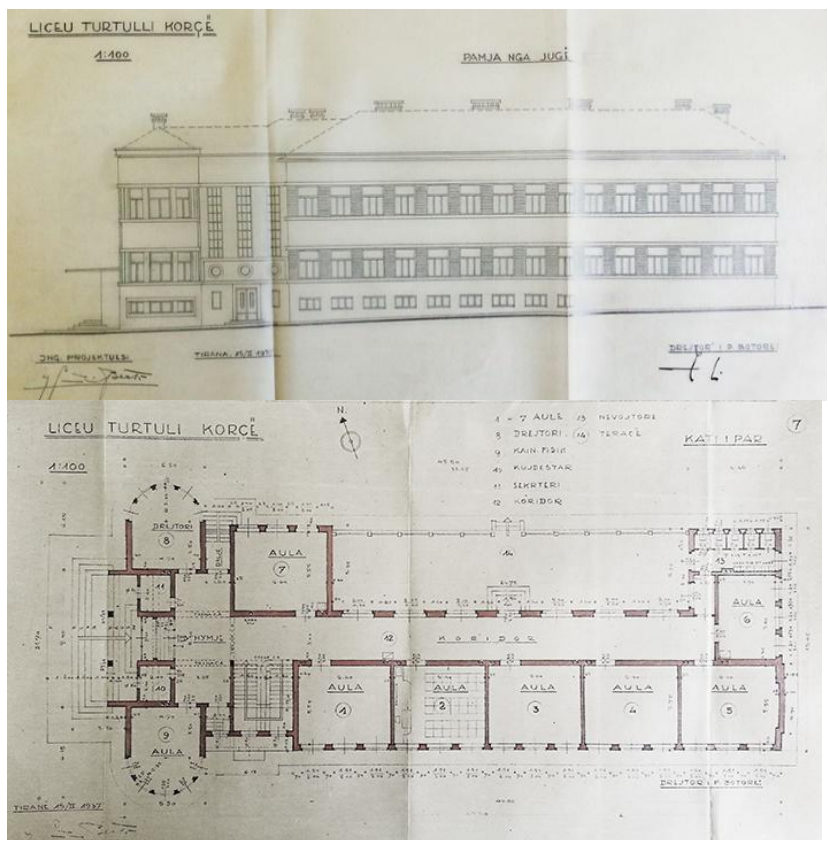

Figure 13: Plan and view of the Liceum of Korce, Albania, Giulio Berte architect. Courtesy of Central Construction Archive.

Italian architects had the opportunity to explore, to seek themselves in the field of architecture trying to restore elements of Italian architecture in a different context outside their country and inserting an identity of modern architecture. "Roots of Italian architecture should not be viewed with nostalgia but as a language which is alive and which can be taken as a model of inspiration for the future architecture. [6] 


\section{International Journal of Science and Research (IJSR) \\ ISSN (Online): 2319-7064}

Index Copernicus Value (2013): 6.14 | Impact Factor (2015): 6.391

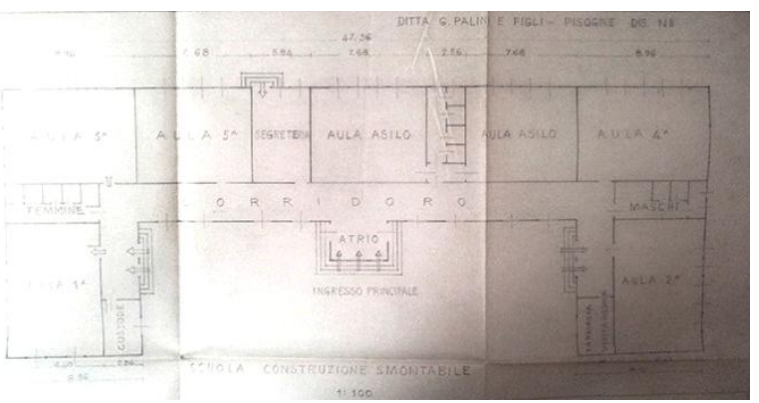

Figure 14: The plan of the typical standard school applied by the Italians during the 1939, in almostevery city of

Albania. Courtesy of Central Construction Archive.

\section{The influences during the Communist Period, 1944-1990.}

After the Second World War, in November 1944 the communist regime was set. Albania which wasleft alone, without help and money relied on the Soviet regime. Albania had a noticeable impedimentin many fields, especially in that of education. Over $80 \%$ of Albanian population was illiterate and many villages lacked primary schools. The uneducated population resulted also by the nonattendance of the youth in theschools built by Italians. Academics noticed that Albanian youth had no other way of opposing the invaders and abandoned the education leaving the Italian built schools ${ }^{e e}$ structures as empty shells. [10]

According to Koliqi education in this period can be set in different stages: when the education sector grow and took a real physiognomy and stages when the structures suffered the abandoningof schools and the poor income in the field of education [2].

During the communist period the education sector grew in a very vigorous quantitative way and this is proven by the big number of buildings constructed mostly in every part of Albania.

A lot of Albanian students went to Soviet universities bringing the culture, traditions and knowledge to their country. This is reflected in the architecture of the period which is very monumental and with a defined symmetry.

Until 1970, Albania opened 1374 primary schools, 53 technical and professional schools, 46 secondary schools of general education, 85 vocational, industrial, agricultural, educational, etc., and 5 universities. [2] "The greatest development in the educational system happened during the years 1950-1955, when Albanian schools received full physiognomy but at the same time, there was a strong impact from the experience of the Soviet school and pedagogy." [16]

For a long time during communist period the education area had an essentially Marxist-Leninist ideological axis, which was reflected in the curriculum reforms, programs and educational system. The basic principles were of 'learningworking-producing- physical and military education. [2]

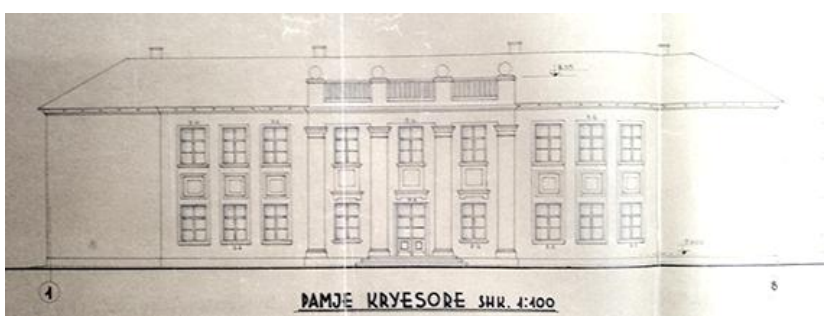

Figure 15: Elevation of a standard secondary school designed in 1953. Courtesy of Central Construction Archive

The school's architecture in Albania wasplannedby the State Institute of Design (InstitutiShteteroriProjektimit) and wasknown for the standardization, their uniformity and the minimal cost. "The choice of this typology wasdriven primarily by the minimization of construction costs." [17]The communist government adopted a standardized aesthetic of multi-section low-rise school buildings (1-3 stories). Schools built during the last decades of the $20^{\text {th }}$ century were therefore largely standardized, utilitarian spaces that were designed to house as many students as possible, maximizing classroom space. They were similar to each other and change very little from one city to another.

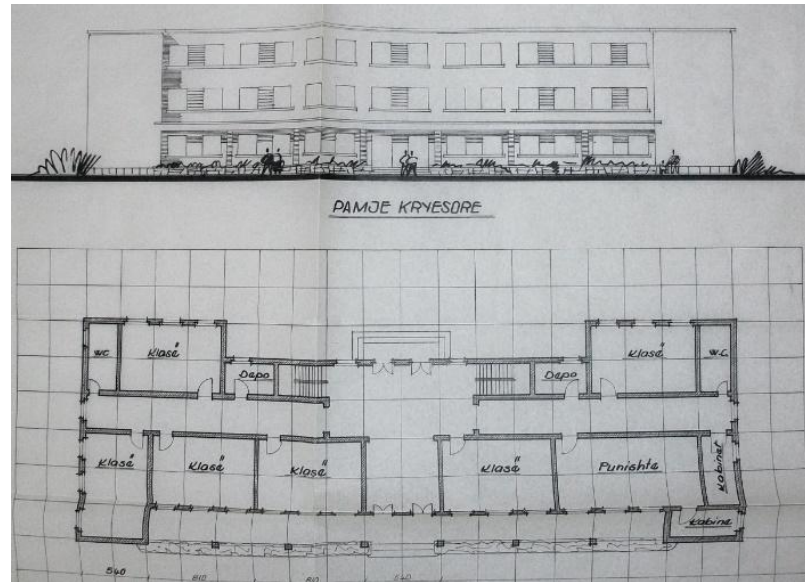

Figure 16: Plan and elevation of a typical standard secondary school in Albania, widespread in big cities during the 1960-1970. Courtesy of Central Construction Archive

The end of the communist and totalitarianstate in 1990 and the establishment of a new democratically elected government led to drastic economic, social, and physical transformations. [18]

The 1990s were a time of decline and reflection for schools in Albania, as districts saw enrollments go down, while urban schools were working in two shifts and with 50or 60 students in 30 meter square. Classroom investment in school facilities drop, and many busied themselves with smaller renovation projects to keep aging facilities up to basic standards of functionality.

In the last decade of the $20^{\text {th }}$ century there were few significant strides and the education system passed a number of difficulties roughly due to political and economic isolation of Albania. For almost 20 years there were no school built at all and the current typology suffered overcrowded spaces in the urban cities and abandonment in the rural areas. Negative factors were also the reduction of the existing structures and the degradation due to the non- 


\section{International Journal of Science and Research (IJSR) \\ ISSN (Online): 2319-7064 \\ Index Copernicus Value (2013): 6.14 | Impact Factor (2015): 6.391}

maintained buildings, discrepancy between the new pedagogies and the old curricula based on the ideological system and the evolutions in the other sectors.

\section{Conclusions}

The many wars that took place in Albanian territory during the course of history had a huge and strong impact in a lot of areas, and education made no exception. The several invasions and influences of foreign countries left traces in the architecture of this group of buildings and also in the pedagogical field. This article recounts the history and evidences of the foreign influences found in the educational sector. Ottoman Empire, Italian dominations, AustroHungarian, French, Greek invasions and also Russian influences during the communist regime, shaped the architecture of the school environment in Albania. These forces are represented though the rare pictures and plans of some of the most distinct school buildings in Albania.

The architecture of the Albanian education environment was transformed from similar to Ottoman mosques or Catholic monasteries to a more monumental and scenographic display during the Italian dominations; to a rational, simple and economic architecture during communist regime. These identities were imported from abroad (e.g. by hiring foreign designers or copying foreign styles), or were the result of transformational forces from abroad, such as military invasions or theso-called cultural imperialism.

\section{References}

[1] Pasalar, C. (2003). The Effects of Spatial Layouts on Students' Interactions in Middle Schools: Multiple Case Analysis. North Carolina: Faculty of North Carolina State University.

[2] Koliqi, H. (2002). Historia e arsimit dhe e mendimit pedagogjik Shqiptar. Prishtine: Universiteti i Prishtines: Fakulteti Filozofik, Libri Shkollor.

[3] Ceka, N. (2003). Edukata dhe arsimi ne lashtesi. In M. e. Shkences, Historia e Arsimit dhe e Mendimit Pedagogjik Shqiptar (pp. 13-23). Tirane: Instituti i Studimeve Pedagogjike.

[4] Catherine Burke \& Ian Grosvenor. (2008). School. London, UK: Reaktion Books Ltd.

[5] Dedja, B. (2003). Vazhdimesia iliro-shqiptare ne fushen e edukates dhe te arsimit. In M. e. Shkences, Historia $e$ Arsimit dhe e Mendimit Pedagogjik Shqiptar (pp. 2441). Tirane: Instituti i Studimeve Pedagogjike.

[6] Vokshi, A. (2014). Tracce dell'architettura Italiana in Albania 1925-1943.Firenze: DNA Editrice.

[7] Dedej, S. (2003). Arsimi dhe mendimi pedagogjik ne Mesjete. In M. e. Shkences, Historia e Arsimit dhe e Mendimit Pedagogjik Shqiptar, V.1 (pp. 43-88). Tirane: Instituti i Studimeve Pedagogjike.

[8] Anne-Marie Chatelet, Marta Gutman. (2004). School Buildings and architecture. In P. S. (editor), Encyclopedia of children and childhood in history and society (pp. 726-728). New York: Macmillan reference, USA

[9] Gecaj, M. (2008). Neperudhet e shkollesShqipe.Tirane: Botimet "Erik".
[10] Rama, F. (2005). Dukuri arsimore gjate Luftes se Dyte Boterore ne Shqiperi. Tirane: Argenta-LMG.

[11] Kashari, Q. (2003). Arsimi kombetar ne shtetin e pavarur Shqiptar. In M. e. Shkences, Historia e Arsimit dhe e mendimit pedagogjik Shqiptar (pp. 262-319). Tirane: Instituti i Studimeve Pedagogjike.

[12] Myziri, H. (2003). Zhvillimiiarsimit ne fund teshekullit XIX dhefillimteshekullit XX, In M. e. Shqiptar, Historia e arsimit dhe e mendimit pedagogjik shqiptar (pp. 121-223). Tirana: Instituti i Studimeve Pedagogjike.

[13] Pojani, D. (2014). Urban design, ideology, and power: use of the central square in Tirana. Planning Perspectives, Taylor \& Francis.

[14]Baker, L. (2012). A history of School design and its Indooor Environmental Standards, 1900 to today. National Institute of Building Sciences. Washington D.C.: National Clearinghouse for Educational Facilities

[15] Osmani, S. (2003). Arsimi dhe mendimi pedagogjik gjate viteve 1914-1920. In M. e. Shkences, Historia e Arsimit dhe e Mendimit Pedagogjik Shqiptar (pp. 320376). Tirane: Instituti i Studimeve Pedagogjike.

[16] Beqja, H. (1974). Politika arsimore marksiste- leniniste e PPSH dhe zbatimi i saj ne jete.Tirane: Revista pedagogjike, Nr. 5.

[17] Kolevica, P. (Tirana). Arkitektura dhe diktatura. 1997 Marin Barleti.

[18] Gjokuta, I. G. (2008). Migrant cities research: Tirana. Tirana: British Council, Living Together Program. 